\title{
Nation Wealth's Legal Position that Separated on PT Indonesia Asahan Alumunium as Main Holding of State Owned Enterprise for Mining Industry Based on Justice Principles
}

\author{
Kusmono \\ STAN Polytechnic of State Finance \\ Finance Education and Traning Agency, MoF \\ Jakarta, Indonesia \\ kusmono@pknstan.ac.id
}

\author{
Rudi Margono \\ Hight Prosecutor's Office \\ Jakarta, Indonesia \\ rudimargono06@gmail.com
}

\begin{abstract}
States engaged in economic activities in order to achieve the goals of the state. Law Number 17 of 2003 on State Finance states that the form of state activity in economic activity is conducted through a state enterprise, known as a State-Owned Enterprise in the form of a Persero regulated in Law Number 19 Year 2003 concerning BUMN, stating that the BUMN of a whole business entity or most of the capital is owned by the state through direct inclusion derived from separated state assets. Persero, is a state-owned limited liability company whose capital is divided into shares wholly or at least $51 \%$ (fifty one percent) of its shares owned by the Republic of Indonesia whose main purpose is to pursue profit. BUMN is PT. To strengthen the capital structure and increase the capacity of the Company's business PT Persero Aluminum Limited is determined through Government Regulation Number 47 Year 2017 on Addition of State Equity Participation of the Republic of Indonesia Into Shares of Limited Liability Company PT Indonesia Asahan Alumunium, acting as the parent Company in the field of mining. Several laws governing State-Owned Enterprises in their implementation create a sense of confidence for the Board of Directors of the Company in driving its business in case of loss. The polemic that arises is how the legal status of state equity participation of state assets separated on state-owned company Persero case study on PT Inalum as the holding company holding the mining field? Business is risk. In the event of any loss in the business process of PT Inalum, does the loss include the state loss domain or the loss of the business? Through normative legal research the researcher will do the research.
\end{abstract}

Keywords- State-Owned Enterprise

\section{INTRODUCTION}

Government activities in economic activities are carried out through state companies. Law Number 17 of 2003 concerning State Finance Article 1 number 5 explains that a State Enterprise is a business entity that all or part of its capital is owned by the Central Government. The intended State Enterprise is made through a Business Entity called the State Owned Enterprise (BUMN). Provisions concerning BUMN are further regulated in Law Number 19 of 2004 concerning State-Owned Enterprises. Article 1 nu mber 1 and number 10 states that a State Owned Enterprise is a business entity that all or most of its capital is owned by the state through direct participation derived from the separated state assets, namely state assets derived from the State Budget $(\mathrm{APBN})$ ) to be used as state capital participation in Persero and / or Public Corporation and other limited liability companies.

SOEs include Public Companies (Perum) and the Company (Perseroan) or better known as Persero. Public Company, hereinafter referred to as Peru m, is a State-Owned Enterprise whose entire capital is owned by the state and is not divided into shares, which aims for public benefit in the form of providing high quality goods and / or services while simultaneously pursuing profits based on the company's management principles, thus definition number 4 Article 1 Law Law Number 19 Year 2003. While the Company hereinafter referred to as Persero is regulated in number 2 Article 1 the same Law is stated that a Company Company hereinafter referred to as Persero is a BUMN in the form of a limited liability company whose capital is divided into all shares or at least $51 \%$ ( fifty-one percent) the shares are owned by the Republic of Indonesia whose main objective is to pursue profits.

Persero BUMN as a State Company is one of the economic actors having an important role in driving national perokomian. Judging from the capital structure of the Government taking from the APBN included in the BUMN Persero, the next management is state assets which are separated from the next APBN which will become the capital of the Persero. Paragraph (1) Article 4 of Law 19 of 2003 states that SOE Capital is and originates from separated state assets. The company obtains its capital derived from state assets which are separated from the state budget through Government Regulation (PP).

The govemment encourages the formation of a holding company per industrial sector, this is partly intended to strengthen the capital structure and increase business capacity. In the mining sector, PT Indonesia Asahan Aluminum company was established as the mining sector holding company through Government Regulation No. 47 of 2017 concerning the Addition of State Capital Participation of the Republic of Indonesia to the Shares of PT Indonesia Asahan Aluminum Company, acting as the parent company in the mining sector with capital derived from the transfer of all Series B shares owned by the Republic of Indonesia in a 
Company (Persero) PT Aneka Tambang Tbk, PT Bukit Asam Tbk (Persero) Company, and PT Timah Tbk (Persero) and all Republican State-owned Companies Indonesia to PT Freeport Indonesia.

Business is a risk, in the midst of a competitive global economic competition business Indonesian Persero's Board of Directors Asahan Alumunium in moving its business wheels certainly depends on business risks that will not always bring profit but also carry the risk of loss. When PT. Indonesia Asahan Alumunium suffered a loss in its business transactions, did the loss fall into the realm of state loss? To answer the polemic, it is necessary to first conduct a normative legal research on how the position of the separated state assets is included as the participation of government capital to Indonesian Asahan Aluminum Corporation? Is the nature of the state / government involved in economic activities?

\section{DISCUSSION}

The State / Government involved in economic activities is carried out in order to fulfill the obligations of the state to achieve the goal of the state, namely to educate the life of the nation, the realization of a just, prosperous and prosperous society as mandated in the opening of the 1945 Constitution.

The role of the state / government in this economic activity has been around for a long time. In countries with a socialist understanding the role of the state in economic activities is very centralistic, while in liberal countries the opposite is where the role of the state is minimal, the state / government is only a regulator with an economy based on the principles of a market mechanism that emphasizes on the efficiency side.

Adam Smith (1723-1790), in his book published in 1776, entitled: An Inquiry Into the Nature and Causes of Wealth of Nations or better known as the Wealth of Nation. In natural freedom, the government only has three tasks and functions, namely protecting the community from acts of violence and invasion from other free societies, protecting every me mber of society from injustice by other members of the community, and providing public infrastructure (public utilization) that cannot be realized by community member. The concept of the task and function of the government of Adam Smith led to the birth of the concept of wealfare state.

In order to achieve the goals of the state towards a just and prosperous society as mandated in the opening of the 1945 Constitution requires great resources. The ruler has been chosen by the people through a political / social contract where the people give the mandate of the elected ruler to lead and bring the people he leads towards the goal of statehood. The state will guarantee justice and welfare of the people. The ruling country turned out to be supported by its people. The state then provides a constitutional basis for the government to exercise its power. A social contract is a rational theory that has the assumption that the formation of a country is based on an agreement from the community. (The social contract theory of John Lock and Thomas Hobbes).

The 1945 Constitution as a written constitution is a written guideline for this nation to achieve the goals of the state to be achieved and has become a commitment of the Indonesian nation through the Founding Father of the nation when formulating and establishing the 1945 Constitution as a written constitution as in the opening of the Act Base 1945 Fourth paragraph. The realization of the purpose of the state, the implementation of the rule of law which welfare the people requires great resources. Resources are obtained, among others, through the management of state assets. Provisions regulate in the event that the state is actively involved in economic activities through a Legal Entity known as a State-Owned Enterprise. In the case of state wealth, the Constitution of the 1945 Constitution regulating in Article 33 paragraph (2) states: "Production branches that are important to the state and which control the lives of many people are controlled by the state." Then Article 33 paragraph (3) of the 1945 Constitution which states: "Earth and water and the natural resources contained therein are controlled by the state and used for the greatest prosperity of the people."

In the Indonesian legal system it is possible for the Government to be directly involved in economic activities. In the direct activities of the economy, the Government "took off his clothes" and acted as investors, where the capital was taken from state assets originating from the state budget, which was orig inally separated from state assets and the state assets were separated from the state enterprises.

The BUMN management institution in Indonesia is generally carried out by the Ministry of State-Owned Enterprises, in addition to several BUMNs that are managed directly under the Ministry of Finance. In the Ministry of State-Owned Enterprises Ministry, SOEs have the task of organizing affairs in the field of development of SOEs in the government to assist the President in organizing state government.

Persero BUMN as a State Company is one of the economic actors having an important role in driving national perokomian. In the mining sector, the government has formed a parent company (holding) through the Persero Indonesia Aluminum Asahan. In the midst of tight global competition and to strengthen the capital structure and increase the business capacity of PT Indonesia Asahan Aluminum Company, the government has added the Republic of Indonesia's Capital Participation to the Mine Tbk, PT Bukit Asam Tbk Company and the Company The Company (Persero) PT Timah Tbk and all shares owned by the Republic of Indonesia in the share capital of PT Indonesia Asahan Aluminum Company which came from the transfer of all State Series B shares of the Republic of Indonesia to PT Aneka T Freeport Indonesia through a Government Regulation No. 47 of 2017 concerning the Addition of State Capital Participation of the Republic of Indonesia to the Share Capital of the Company's Company (Persero) PT Indonesia Asahan Alumunium.

PT Indonesia Asahan Aluminum, obtaining its status as a Company (Persero) was determined based on Government Regulation Number 26 Year 2014 concerning the Establishment of PT Indonesia Asahan Aluminum as a PT Indonesia Asahan Aluminum Company. With this stipulation, the status of Indonesian Asahan Alumni PT Indonesia became BUMN Persero as stipulated in Law Number 19 Year 2003 concerning State-Owned Enterprises. Persero, is a SOE in the form of a limited liability company whose capital is divided into shares which all or at least $51 \%$ (fifty one percent) of its shares are owned by the Republic of Indonesia whose main objective is to pursue profits, according to Article 1 paragraph 2 of the BUMN Law. 
PT Indonesia Asahan Alumunium's capital was acquired as a result of the transfer of shares owned by Nippon Asahan Aluminum Co., Ltd. to PT Indonesia Asahan Aluminum to the State amounting to $58.88 \%$ (fifty eight point eighty eight percent). With the transfer of Nippon Asahan Aluminum Co., Ltd. shares The value of the Republic of Indonesia State capital participation in the PT Indonesia Asahan Aluminum Company which was $41.12 \%$ (forty one point twelve percent) was $100 \%$ (one hundred percent). For the transfer of Nippon Asahan Aluminum Co., Ltd. shares Thus, the State provides compensation with funds sourced from APBN 2012 and APBN 2013.

Judging from the capital structure, the Government takes from the APBN included in the BUMN Persero, the next management is a state asset which is separated from the next APBN which will become the capital of the Persero. Paragraph (1) Article 4 of Law 19 of 2003 states that SOE Capital is and originates from separated state as sets.

The separated state assets are carried out by the government through government capital participation with Government Regulations originating from the National Budget. Law Number 17 of 2003 concerning State Finance explains in Article 2 that in paragraph $g$ that state assets separated from state enterprises are part of the scope of State Finance. Subsequently article 1 number 5 of the same law describes State Enterprises as business entities that all or part of their capital is owned by the Central Government. The State Enterprise referred to is carried out through a Business Entity called the State-Owned Enterprise (BUMN) which is further regulated in Act Number 19 of 2004 concerning State-Owned Enterprises. Article 1 number 1 and number 10 states that a State-Owned Enterprise is a business entity that all or most of its capital is owned by the state through direct participation derived from the separated state as sets, namely state as sets derived from the State Budget (APBN) to be used as state capital participation in Persero and / or Public Corporation and other limited liability companies.

SOEs include Public Companies (Perum) and the Company or better known as Persero. Public Company, hereinafter referred to as Perum, is a State-Owned Enterprise whose entire capital is owned by the state and is not divided into shares, which aims for public benefit in the form of the provision of high quality goods and / and services while simultaneously pursuing profits based on the principles of company management. 1 Law Nu mber 19 Year 2003. While the Company hereinafter referred to as Persero is regulated in number 2 Article 1 the same Law is stated that the Company hereinafter referred to as Persero is a BUMN in the form of a limited liability company whose capital is divided into all or at least 51 shares \% (fifty one percent) of its shares are owned by the Republic of Indonesia, whose main objective is to pursue profits

Government capital participation in BUMN Persero Asahan Alumunium can be constructed that the people as sovereign through the House of Representatives with the stipulation of legislation to settle to the president acts as the holder of state finance, Chief Executive Officer (CEO), Minister of Finance acts as State General Treasurer, The Chief Financial Officer (CFO), and the Deputy Government as the owner of the separated state as sets delegate their authority to the Minister of SOE as the technical manager representing the government as the shareholder through the
GMS. In its operational motion, it is carried out through the Persero organs (Directors, Board of Commissioners).

The Board of Directors representing Persero which has been given the mandate by the shareholders drives the business wheel of the company to be careful, well-acted in accordance with the Persero's articles of as sociation and / and in accordance with the laws and regulations. (principle of the business judgment rule)

The Company is a Limited Liability Company (PT) whose regulation is subject to Law Number 40 of 2007 concerning Limited Liability Companies. The participation of govemment capital from the separated state assets originating from the APBN to the Indonesian Persero Asahan Alumunium, furthermore the management is carried out in corporate governance, no longer based on APBN governance. Because it is in the form of a Limited Liability Company, all provisions and principles applicable to limited liability companies as stipulated in Law Nu mber 40 of 2007 concerning Limited Liability Companies apply to limited liability companies.

\section{CONCLUSION}

Based on our research with normative legal conducted, several points can be summarized as follows:

1. The inclusion of government capital derived from state assets that are separated to Persero Indonesia Asahan Aluminum continues to be metaphorous as a state capital in the form of shares, the management subsequently is not subject to the mechanism of state budget management but according to the corporate mechanism. If the company experiences losses in business carried out in accordance with the principles of the business judgment rule, it is a business risk, but the legal construction of the participation of state or government capital derived from the separated state assets is part of the state's finances.

2. The government involved in economic activities by managing and controlling state assets by obtaining a mandate fro $m$ the people through a political contract with the DPR holding a government based on law is essentially to achieve the goal of state as mandated in the fourth paragraph of the opening of the 1945 Constitution.

\section{REFERENCES}

[1] A Basiq Djalil, Logika (Ilmu Mantiq), Fajar Interpratama Offset, cetakan 1, Jakarta, 2010.

[2] Aziz, Chandra Dinata..., Menggugat Negara, Dialektika Ekonomi Politik, Hukum, dan Civil Society, Intrans Publishing, Malang, 2016.

[3] Abdul Latif, Hasbi Ali, Politik Hukum, Sinar Grafika, Rawamangun, 2010

[4] Achamd Gozali, Anies M. Basalamah, Hukum Administrasi Keuangan Negara, Cetakan Pertama, Jakarta, 2002.

[5] Adrian Sutedi, Hukum Keuangan Negara, Sinar Grafika, Jakarta, 2010.

[6] Agus Sardjono, Pengantar Hukum Dagang, Rajawali Pers, Jakarta, 2016

[7] Al Marsudi, Subandi, Pancasila dan UUD 1945 Dalam Paradigma Reformasi, RajaGrafindo Perkasa, Jakarta, 2004.

[8] Alex, Penyunting, Amandemen UUD 1945 \& Reshuffle Kabinet Kerja Jokowi-JK (Seri Perundang-Undangan), Cakrawala, Yogyakarta, Cetakan Pertama, 2015

[9] Amsal Bakhtiar, Filsafat Ilmu, Rajawali Pers, cetakan ke 11, Jakarta, 2012 
[10] C.S.T. Kansil, Pengantar Ilmu Hukum dan Tat a Hukum Indonesia Jilid I, Pengantar Ilmu Hukum (Semester Ganjil), Balai Pustaka, Jakarta.

[11] ------, Pengantar Ilmu Hukum dan Tata Hukum Indonesia Jilid II, Pengantar Hukum Indonesia (Semester Genap), Balai Pustaka, Jakarta

[12] ------, Pengantar Ilmu Hukum Jilid II, Balai Pustaka, cetakan kesembilan, 1993.

[13] Hamidi, Metode Penelitian Kualitatif, UMM Press, cetakan kedua, Malang, 2010.

[14] Hamid Attamimi dalam Ridwan, Diskresi dan Tanggungjawab Pemerintah, FHUIIPress, Yogyakarta, 2014.

[15] Hans Kelsen, Dasar-Dasar Hukum Normat if, Nusa Media, Bandung 2008.

[16] Ibrahim, Johnny, 2006. Teori \& Metodologi Penelitian Hukum Normatif.

[17] Iramihardja, Pengantar Filsafat (Sistematika Filsafat, Sejarah Filsafat, Logika dan Filsafat Ilmu (Epistemologi), Metafisika dan Filsafat Manusia, Aksiologi), PT Refika Aditama, Bandung, 2006.

[18] Inu Kencana Syafiie, Pengantar Filsafat, Refika Aditama, cetakan kedua, 2007.

[19] Ishaq, Dasar-Dasar Ilmu Hukum, Sinar Grafika, Jakarta, 2010.

[20] Jimly Asshiddiqie, Konstitusi Ekonomi, PT Kompas Media Nusantara, Jakarta, 2016.

[21] --------, Pengantar Ilmu Hukum Tata Negara, PT RajaGrafindo Persada, cetakan ke-2, jakarta, 2010.

[22] Karen Lebacqz, Teori-Teori Keadilan, Six Theories of Justice, Suplemen; Konsep Keadilan Dalam Kristen, oleh Hans Kelsen, diterjemahkan oleh Yudi Santoso, Penerbit Nusa Media, Bandung, 2011.

[23] K.J.C.T. Simorangkir, Rudy T. Erwin, J.T. Prasetyo, Kamus Hukum, Sinar Grafika, cetakan kelima belas, Jakarta, 2013

[24] Louis O. Kattoff, Elements of Philosophy, The Ronald Press Company, New York, Alih bahasa Soejono Soemargono, Terjemahan bahasa Indonesia, Pengantar Filsafat, Tiara Wacana Yogya, 2004.

[25] Mark B. Woodhouse, A Preface to Philosophy, Edisi ke-3, Wadswort. A Division of International Thomson Publish Belmont, 1984, Ahmad Norma Permata, P. Handoko Hadi, Berfilsafat : Sebuah Langkah Awal, Penerbit Kanisius, Yogyakarta, Edisi Indonesia, 2000.

[26] Marzuki, Peter Mahmud, 2005, Penelitian Hukum.

[27] Muhammad Sood, Hukum Perdagangan Internasional, Ed 1-2, Rajawali Pers, Jakarta, 2012

[28] Muh. Arief Effendi, The Power of Good Corporate Governance Teor dan Implementasi, Salemba Empat, Edisi 2, Jakarta Selatan, 2016

[29] Mundiri, Logika, RajaGrafindo Persada, Jakarta, 2005.

[30] Muhammad Sood, Hukum Perdagangan Internasional, Rajawali Pers, Jakarta, 2012

[31] Moh. Mahfud, Politik Hukum di Indonesia, Rajawali Pres, Cetakkan keempat, Jakarta, 2011.

[32] Montesquieu, The Spirit of Laws, University of California Press, 1977, Penerjemah M. Khoiril Anam, Penerbit Nusamedia, Bandung, 2007.

[33] Nasution, Bismar dan Sitompul, Zulkarnain, 2005, Hukum Perusahaan.

[34] Norman K. Denzin \& Yvonna S. Lincoln (Eds.), Handbook of Qualitative Research, Sage Publication. Pvt. Ltd. Penerjemah Dariyatno, Badrus Samsul Fata..., Pustaka Pelajar, Cetakan pertama 2009.

[35] Peter Mahmud Marzuki, Pengantar Ilmu Hukum, Kencana Prenada Media Group, Jakarta, 2008.

[36] Poespoprodjo W, Logika Ilmu Menalar, Pustaka Grafika, cetakan ke II, Bandung 2006.

[37] Rahmat Trijono, Dasar-dasar Ilmu Pengetahuan Perundang-undangan, Papas Sinar Sinanti, Jakarta, 2014.

[38] Rajagukguk, Erman, 2006, Nyanyi Sunyi Kemerdekaan Menuju Indonesia Negara Hukum Demokratis.

[39] Reiner, Kraakman R, Business Law, 2005, The Anatomy of Corporate Law: A Comparative and Functional Approach.
[40] Ridley, Ann, 2005, Key Facts Company Law.

[41] Rido, Ali, 1983, Badan Hukum dan Kedudukan Badan Hukum Perseroan, Perkumpulan, Koperasi, Yayasan, Wakaf.

[42] Riduan Syahrani, Seluk Beluk dan Azas Hukum Perdata, PT Alumni, Bandung, 2010

[43] Safi, Politik Hukum Penyatuan KewenanganJudicial Review, Diva Press, Yogyakarta, 2016.

[44] Satjipto Raharjo, Ilmu Hukum, PT Citra Aditya Bakti, ceatakan ke VIII, Bandung, 2014.

[45] Sjahchran Basah, Eksistensi dan Tolak Ukur Badan Peradilan Administrasi di Indonesia, FHUII Press, Yogyakarta, 2014.

[46] Subekti, Pokok-Pokok Hukum Perdata, PT Intermasa

[47] Sulistiowati, Aspek Hukum dan Realitas Bisnis Perusahaan Grup di Indonesia, PT Erlangga.

[48] Soeria Atmadja, Arifin P, 2005, Keuangan Publik Dalam Prespekt if Hukum Praktik, dan Kritik.

[49] Solomon, Lewis D, Schwartz, Donald E, Bauman, Jeffrey D, dan Weiss, Elliott J, 1994, Corporations Law And Policy Material And Problems.

[50] Sugiyono, 2001, Metode Penelitian Administrasi.

[51] Sulistiowati, Aspek Hukum dan Realitas Bisnis Perusahaan Group di Indonesia, Erlangga, 2010.

[52] Taufiq Effendi, Reformasi Birokrasi dan Iklim Investasi, Konstitusi Prees, cetakan pertama, 2013.

[53] Tanya L Benart, Yoan N. Simanjuntak dan Markus Y. Hage, Teori Hukum, Strategi Tertib Manusia Lintas Ruang dan Generasi, Genta Publishing, Yogyakarta, 2013.

[54] Theodorus M. Tuanakotta, Menghitung Kerugian Negara Dalam Tindak Pidana Korupsi, Salemba Empat, Jakarta, 2009.

[55] Tim Penulis, Religiousitas Sains, Meretas Jalan Menuju Peradaban Zaman (Diskursus Filsafat Ilmu), UB Press, cetakan Pertama, Malang, 2010.

[56] Zainal Arifin, Filsafat Ilmu, Pena Kadiri Publishing, cetakan 1, 2009, Kediri.

[57] Zainal Asikin, Hukum Dagang, PT RajaGrafindo Persada, Jakarta, 2014.

[58] Seminar Nasional Aspek Hukum Pengelolaan Keuangan Negara Bagi Kuasa Pengguna Anggaran, 2015. Pusdiklat Anggaran dan Perbendaharaan, Badan Pendidikan dan Pelatihan Keuangan, Kementerian Keuangan.

[59] Seminar BUMN 2018, Studi Benchmarking BUMN Update 2018, T oto Pranoto, Manajing Director LM FEB UI 2018, Januari 2018.

\section{Peraturan Perundangan}

[60] Undang-Undang Dasar 1945.

[61] -------- Nomor 17 Tahun 2003 Tentang Keuangan Negara.

[62] ---------Nomor 19 Tahun 2003 Tentang Badan Usaha Milik Negara.

[63] ---------Nomor 1 Tahun 2004 Tentang Perbendaharaan Negara.

[64] ------- Nomor 15 Tahun 2004 Tentang Pemeriksaan Pengelolaan dan Tanggung Jawab Keuangan Negara.

[65] ------ Nomor 25 Tahun 2004 Tentang Sistem Perencanaan Pembangunan Nasional.

[66] ------- Nomor 40 Tahun 2007 Tentang Perseroan Terbatas.

[67] ------ Nomor 4 Tahun 2009 Tentang Pertambangan Mineral dan Batubara.

[68] Peraturan Pemerintah Nomor 72 tahun 2016 Tentang Perubahan Atas Peraturan Pemerintah Nomor 44 Tahun 2005 Tentang Tata Cara Penyertaan dan Penatausahaan Modal Negara Pada Badan Usaha Milik Negara dan Perseroan Terbatas.

[69] ------ Nomor 47 Tahun 2017 Tentang Penambahan Penyertaan Modal Negara Republik Indonesia Ke Dalam Modal Saham Perusahaan Perseroan (Persero) PT Indonesia Asahan Alumunium 